\title{
The Moderating Effects of Organizational Culture on the Relationship between Work Motivation and Work Commitment of University Academic Staff
}

\author{
Saira Irfan (Corresponding author) \\ Universiti Utara Malaysia, Malaysia. \\ E-mail: sairairfan2005@gmail.com \\ Najib Ahmad Marzuki \\ UUM College of Arts and Sciences \\ Universiti Utara Malaysia \\ E-mail: najib320@uum.edu.my
}

Received: January 15, 2018

Accepted: February 5, 2018 Published: February 27, 2018

doi:10.5296/ijld.v8i1.12484

URL: https://doi.org/10.5296/ijld.v8i1.12484

\begin{abstract}
The link between the work motivation and work commitment is well established in a variety of work settings. However, the role of organizational culture is not explored in depth, especially as a moderator between work motivation and work commitment. The present study undertakes an examination of the above explained model. The sample consisted of 351 academics from nine public universities in the state of Punjab, Pakistan. Cross-sectional survey design was employed to collect the data. The statistical analyses were performed with Partial Least Squares technique using the Smart PLS 3.0. The findings revealed that adhocracy culture moderates the link between non-self-determined work motivation and work commitment among university academic staff. The study has implications for authorities to capitalize on organizational culture to boost work motivation that will ultimately improve work commitment among academics.
\end{abstract}

Keywords: Organizational culture, work motivation, work commitment, academic staff, partial least square 


\section{Introduction}

Education is a challenging and arduous profession. Academics are imperiled by challenging circumstances that affect their motivation, cause adverse psychological state and precipitate turnover (Viseu, De Jesus, Rus, Canavarro, \& Pereira, 2016). To maintain their strength and exuberance for work, academics are required to preserve their personal commitment to perform at work (Day, 2000). Motivation significantly predicts commitment by encouraging employees to devote time and effort to the organization (University) (Mowday, Steers, \& Porter, 1979). Thus, work motivation is associated with, and influences, the individual's work commitment (Heinz, 2015).

The idea of commitment is fundamental and it is explained as a preference to persist with a certain approach (Morrow, 1993). To understand the multiple foci of commitment, the past researchers studied several interior, or micro, and peripheral, or macro, level commitment foci which develop within and across organizational boundaries (Redman \& Snape, 2005; Becker, 2009). The micro-level foci comprise of commitment to teams and supervisors, top management and customers (Becker, 2009). Commitment to organization, occupation/profession, union and career are included in macro-level research (Vandenberghe, 2009).

Commitment is not a monolithic but rather a multi-faceted concept (Reichers, 1985). Morrow (1993), defined work commitment as an individual's recognition of work ethic, dedication to the career, job involvement and organizational commitment. Increased commitment encourages promptness, regularity, satisfaction, motivation and reduce rate of turnover (Shore, Newton, \& Thornton, 1990). Conversely, outcome of low work commitment are diminished performance, turnover, theft, job dissatisfaction, readiness to relocate and brain drain (Ushie, Ogaboh, \& Okorie, 2015; Khan, 2016; Zardari, 2014).

Since motivation is associated with education quality, engagement, and commitment to the occupation, scholars and authorities are concerned with academics' motivation (De Jesus \& Lens, 2005; Klassen, Al-Dhafri, Hannok, \& Betts, 2011). Previous researchers found autonomous motivation to be associated with organizational commitment, and it is important for the acceptance of organization's objectives and to remain committed to work to achieve them (Otis \& Pelletier, 2005; Richer, Gagne \& Koestner, 2002). Staff with high autonomous work motivation may experience pleasure while performing at work and have unpretentious concern for work related activities (intrinsic work motivation) (Vujcic, Oerlemans, \& Bakker, 2016).

For developing commitment and upgrading performance, organizational culture has a central part (Lok \& Crawford, 2001). Organizational culture of a university denotes the set of common standards and norms that regulate academics' conduct (Schneider, Ehrhart, \& Macey, 2013). Organizational culture should be encouraged to assure motivation of personnel with regard to achieving organizational objectives (Sempane, Rieger, \& Roodt, 2002). Motivated staff feel honored while performing their work and hence take responsibility for organizational triumphs. 


\section{Macrothink Institute ${ }^{\text {tm }}$}

Even though culture is considered one of the most leading analytic organizational frameworks, relatively few empirical investigations have been made in education setting to incorporate culture in the evaluation of commitment. A number of prominent culture scholars have highlighted the importance of understanding the association between culture and commitment. It is particularly evident from the findings of Siehl and Martin (1990) that organizational culture has the potential to exert influence on employees' job satisfaction and commitment. Ngeis-Isik and Gursel (2013) established that organizational culture determines the success of an institution and it significantly influences academics' motivation and satisfaction.

Earlier researchers have emphasized to examine the effect of possible moderators and mediators in the relationship between motivation and organizational commitment (Imran, Allil \& Mahmoud, 2017). Therefore, the present research examined the moderating effects of organizational culture on the relationship between work motivation and work commitment of university academic staff in Pakistan.

\subsection{Conceptual Framework}

A conceptual framework presented in Figure 1, was founded on the present theories and models such as Deci and Ryan's (1985) self-determination theory of motivation, Cameron and Quinn's (1999) competing values framework and Morrow's (1993) work commitment model. It integrates the relationships between work motivation (independent variable) and work commitment (dependent variable). It highlights the role of adhocracy and market organizational culture as the moderator between work motivation and work commitment. It also established the direct effect of work motivation on work commitment.

Based on the research framework, the following hypotheses are developed.

1. Adhocracy culture will moderate the relationship between self-determined work motivation and work commitment among university academic staff in Pakistan.

2. Adhocracy culture will moderate the relationship between non-self-determined work motivation and work commitment among university academic staff in Pakistan.

3. Market culture will moderate the relationship between self-determined work motivation and work commitment among university academic staff in Pakistan.

4. Market culture will moderate the relationship between non-self-determined work motivation and work commitment among university academic staff in Pakistan. 


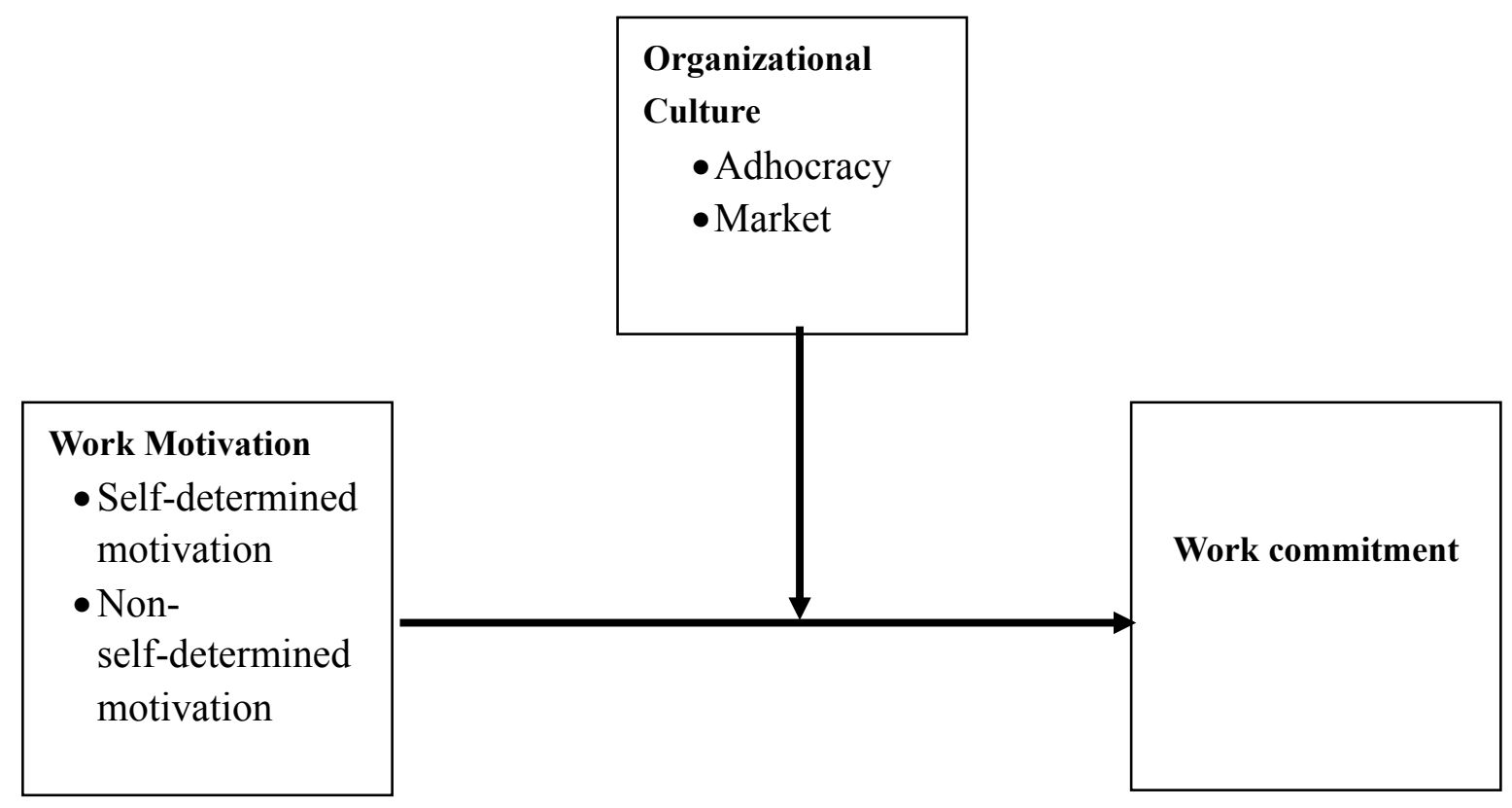

Figure 1. Research Framework

\subsection{Literature Review}

\subsubsection{Work Commitment}

Morrow (1993) defined work commitment as individual's devotion to work ethics, job involvement, organizational commitment and commitment to a career. Morrow's "circles-based" model of work commitment signifies several facets of attachment. These facets range from relatively stable aspects to one that can be manipulated. In his model, the outer circle refers to more manipulative characteristics while the inner circle refers to the relatively stable characteristics. The outward circles are influenced by inward circles but this influence decreases as the outward circle gets farther from the center (Morrow, 1993).

There is a substantial theoretical debate over the development and progressive modifications of commitment. As reported by Mowday, Porter, and Steers (1982), commitment develops within an individual as a sequence of self-regulatory phases of attitudes and behaviors that progress on the job with the passage of time, thereby reinforcing the employee's organizational commitment. Meyer and Allen (1997) proposed that positive work experiences play a role in the development of commitment through social exchange mechanisms. These suppositions indicate that commitment advances with experience in due course. Consequently, the advancement of work commitment can be both positive and negative, and the interaction of the aspects of academics' subjective, workplace and education system influence commitment (Choi \& Tang, 2009). The advantage of investigating other foci of commitment than organizational commitment has been documented through empirical outcomes. As reported by Cohen (2003) employees must show commitment to some entity and if it is not organization then it may be job or career. Opposite of commitment is withdrawal which is 
harmful.

A study revealed moderate level of association between school climate and teachers' commitment. Positive correlation was found between dimension of school climate and teacher commitment. Achievement press was found to have profound effect on teacher commitment than collegial leadership (Othman \& Kasuma, 2017). More generally, empirical findings have revealed that a higher level of affective commitment was related to learning climate which was conducive for innovation and encouraged candid expression of opinion (Southcombe, Fulop, Carter, \& Cavanagh, 2015). Moreover, commitment profiles from different organizations including schools showed that occupational commitment predicts work-related variables. Consonance of occupational and organizational commitment were revealed in four commitment profiles (highly committed, non-committed, affective-normative dominant, continuance dominant). Highly committed profile was found to have a positive effect on pivotal and elective behaviors. It was evident from the findings that relationship between organizational and occupational commitment was based more on compatibility than conflict (Tsoumbris \& Xenikou, 2010).

Karakus and Aslan (2009) found that academics' commitment focuses, level, and variables related to their commitment vary based on their demographic characteristics. Linnansaari-Rajalin and Kivimäki, (2015) found that neighborhood income level and low unemployment rate had significant positive relationship with organizational commitment and job tenure. Whereas professional commitment had fewer consistent associations. In addition, Fransson and Frelin (2016) found that close collegial relationship, positive attitude towards life, humanity and school, and professional development were important factors of teachers' sustained commitment. Teachers disapproved material features like career, stature and a high salary in favor of internal driving forces. Therefore, advanced learning institutions should emphasis on all forms of work commitment rather than just organizational commitment.

\subsubsection{Work Motivation}

Work motivation denotes the intrinsic and extrinsic energies that instigate activities related to work and regulate its form, direction, intensity and duration (Pinder, 1998). Organizational psychology proposes a number of approaches to understand employees' motivation (Gagné et al., 2015); the contemporary theory of motivation - self-determination theory (SDT) addresses the quality rather than quantity of motivation. SDT is concerned with individuals' internal growth inclinations and inherent psychological needs and motivation that direct individuals' choices without external effect. SDT classifies three inherent needs which are competence, relatedness and autonomy. Satisfaction of these needs result in effective working and progress (Deci \& Ryan, 2000).

Fundamental to SDT is the discrepancy between autonomous motivation and controlled motivation. Autonomy involves working with one's own preferences and possessing the right to choose among different alternatives. When individuals involve in a task they find fascinating, they carry out the action volitionally (intrinsic motivation) and personally acknowledge the significance of their tasks as it is related to their integrated sense of self (identified regulation and integrated regulation). Conversely, being controlled includes acting 
with a feeling of coercion and the job is performed to evade guilt feelings and which demands individuals to act with the consideration to support their delicate egos (introjected regulation) and sometimes individuals perform for getting a coveted outcome or staying away from an unfavorable consequence (external regulation). The utilization of external incentives in the initial examinations was basically to instigate controlled motivation (Deci, 1971). SDT proposes that behaviors can be portrayed regarding the extent to which they are self-determined versus non-self-determined. Autonomous motivation and controlled motivation are deliberate, both motivations remain as opposed to amotivation, which includes an absence of expectation and motivation.

Literature indicates that employees' accomplishment in the organization (university) are highly dependent on motivation. An organization cannot compete in the market if it fails to motivate its employees. Motivating features of the institute helps in attracting the competent employees and also retain the current proficient staff (Lee \& Chen, 2013). The study of Gupta and Gupta (2014) and Sinani (2016) also indicated positive correlation between work motivation and organizational commitment and its various attributes. Impact of work motivation and organizational commitment on job performance and job satisfaction was studied in the education sector of Pakistan. Positive relationship was found among the variables (Sohail, Safdar, Saleem, Ansar, \& Azeem, 2014). The findings of Tentama and Pranungsari (2016) showed significant correlation among work motivation, job satisfaction and organizational commitment. Sinclair, Dowson and McInerney (2006) have speculated that teachers' occupational commitment is strengthened by teachers' motivation.

Tella, Ayeni and Popoola's (2007) study found somewhat conflicting results from the previous studies. They attempted to study library personnel in Nigeria to investigate work motivation, job satisfaction, and organizational commitment. Results disclosed positive association between motivation, job satisfaction, and commitment, while motivation and commitment were negatively related. Though, researchers explained the negative relationship in terms of librarians disinterest in profound morals and values concerning the advancement of a mutual vision (Brown \& Sheppard, 1997). Bland et al., (2006) found that faculty on tenure appointments were more prolific and committed in research, education and to their position, and work more than their non-tenure colleagues. Because even in multifaceted organizations like universities, incentive schemes affect efficiency and satisfaction (Lazear, 1998), and that efficiency is more affected by system features than personal features (Deming as cited in Bland et al., 2006). Therefore, authorities should pay attention to the motivational factors which affect academics commitment.

\subsubsection{Organizational Culture}

The core values of an organization in a strong culture are strongly held and shared widely. In other words, when members of an organization accept the shared values, they become more committed to them (Deal \& Kennedy, 1982; Martins \& Martins, 2003). Towers (2006) maintained that a strong organizational culture was associated with employees' motivation. Whereas, organizations having weak culture were transient and sustained primarily by a few executives of the organization. The culture type manifested in the organization explained the 
efficiency of the personnel in terms of performing their designated jobs and actualizing their potential adequately, when both the organizational culture and staff motivation were compatible (Wallach, 1983).

Quinn and Rohrbaugh (1981, 1983) proposed Competing Value Framework (CVF) to investigate the main causes of organizational effectiveness. The chief idea of this model is structured around two dimensions. The first dimension discusses external or internal focus of the organization. The second dimension plans the extent to which an organization emphasises individuality and flexibility, as opposed to control and stability. The crossings of two dimensions create four types of leading organizational culture: hierarchy, clan, market and adhocracy.

Organizational environment should be conducive for trust which makes the staff feel that their organization is prepared to take challenges, and is ready to experience and invest in innovative ideas (Hamdy, Aziz, \& Rizkallah, 2015). Cucu-Ciuhan and Guita-Alexandru (2014) examined the existing and preferred culture of organization from employees' point of view in Romanian state university. Results revealed that university's current culture was power type but employees preferred support type of culture. Teachers had high self-actualization motivation. The study by Panagiotis, Alexandros and George (2014) revealed a negative correlation between motivation level and hierarchy culture, whereas there was positive correlation between motivation and clan culture. Alvi et al. (2014) conducted a study and concluded that supportive and bureaucratic cultures significantly influence employee commitment and job satisfaction, while innovative culture had no effect on employee commitment and job satisfaction.

\section{Method}

\subsection{Participants and Procedures}

A cross-sectional survey design was employed in this study. A random sample of academics was recruited from nine universities, located in the province of Punjab Pakistan. Sample consisted of 351 academic staff from public universities. There were 213 males and 138 females, with an average age of 25 to 34 years participated in the study.

\subsection{Instruments}

In this study, work commitment was measured by Work Commitment Index (Blau, Paul, \& St. John, 1993), consisted of 31 items. WCI uses a 6 point Likert scale (1, strongly disagree to 6 , strongly agree). Reported Cronbach's alpha coefficient in the past studies was 0.72 (Divkan et al., 2013) and in the present study Cronbach's alpha coefficient was 0.90.

To measure work motivation, Work Extrinsic Intrinsic Motivation Scale (Tremblay, Blanchard, Taylor, Pelletier, \& Villeneuve, 2009) was applied. The eighteen items scale in its recent version supports the 6 factor structure of self-determination theory and each factor is represented by 3 items. Scoring range from (7) "Corresponds exactly" and (1) "Doesn't correspond at all". Reported Cronbach alpha values for work self-determined and non-self-determined motivation were .87 and .72 (Tremblay et al., 2009) and in the present 


\section{Macrothink}

International Journal of Learning and Development

ISSN 2164-4063 2018, Vol. 8, No. 1

study Cronbach's alpha coefficient was 0.95 and 0.91 respectively.

Organizational Culture Assessment Instrument (OCAI) was applied to measure organizational culture. Modified version of the OCAI rooted in the competing value framework was introduced by Cameron and Quinn (1999). The 24 items instrument consists of four subscales named as clan, adhocracy, market, and hierarchy. Previously, Cronbach's alphas range between .58 to .88 were reported by Colyer (2000) and in the present study Cronbach's alpha coefficient was 0.83 . OCAI offered five-point Likert scale ranging from (5) strongly agree to (1) strongly disagree.

\section{Results}

The statistical analyses were performed with Partial Least Squares (PLS) technique using the Smart PLS 3.0 software (Ringle, Wende, \& Becker, 2015).

\subsection{Measurement Model Evaluation}

For the assessment of measurement model, the widely used practice is to calculate convergent and the discriminant validity by conducting confirmatory factor analysis (CFA). Factor loadings, average variance extracted (AVE) and also the composite reliability were examined to ascertain convergent validity (Gholami, Sulaiman, Ramayah, \& Molla, 2013). All loadings were greater than 0.6 except one that was .52 , the composite reliabilities were greater than 0.7 and the AVE values were greater than 0.5 as proposed by Hair, Hult, Ringle and Sarstedt (2014).

Subsequently discriminant validity was estimated to measure idiosyncratic concepts as suggested by Fornell and Larcker (1981). It can be seen in Table 1 that values on the diagonal were greater than the other values presented in parallel rows and columns, and also higher than 0.05 signifying the discriminant validity.

Table 1. Discriminant Validity

\begin{tabular}{llllll}
\hline & NSDM & SDM & WC & Adho & Mar \\
\hline Non-self-determined Motivation & $\mathbf{0 . 7 6 9}$ & & & & \\
Self-determined Motivation & -0.393 & $\mathbf{0 . 8 7 3}$ & & & \\
Work Commitment & -0.671 & 0.732 & $\mathbf{0 . 8 0 1}$ & & \\
Adhocracy & -0.455 & 0.782 & 0.734 & $\mathbf{0 . 8 6 4}$ & \\
Market & 0.348 & -0.073 & -0.252 & 0.042 & $\mathbf{0 . 7 3 0}$ \\
\hline
\end{tabular}

[NSDM: Non-self-determined motivation; SDM: self-determined motivation;

WC: Work commitment; ADHO: Adhocracy; Mar: Market]. 


\section{Macrothink}

\subsection{Assessment of Significance of the Structural Model}

The aforementioned assessments helped in accomplishing the inner model, which provided the foundation for testing hypotheses by computing path coefficients and t-values. A bootstrapping process with 500 resamples was run in the Smart PLS.

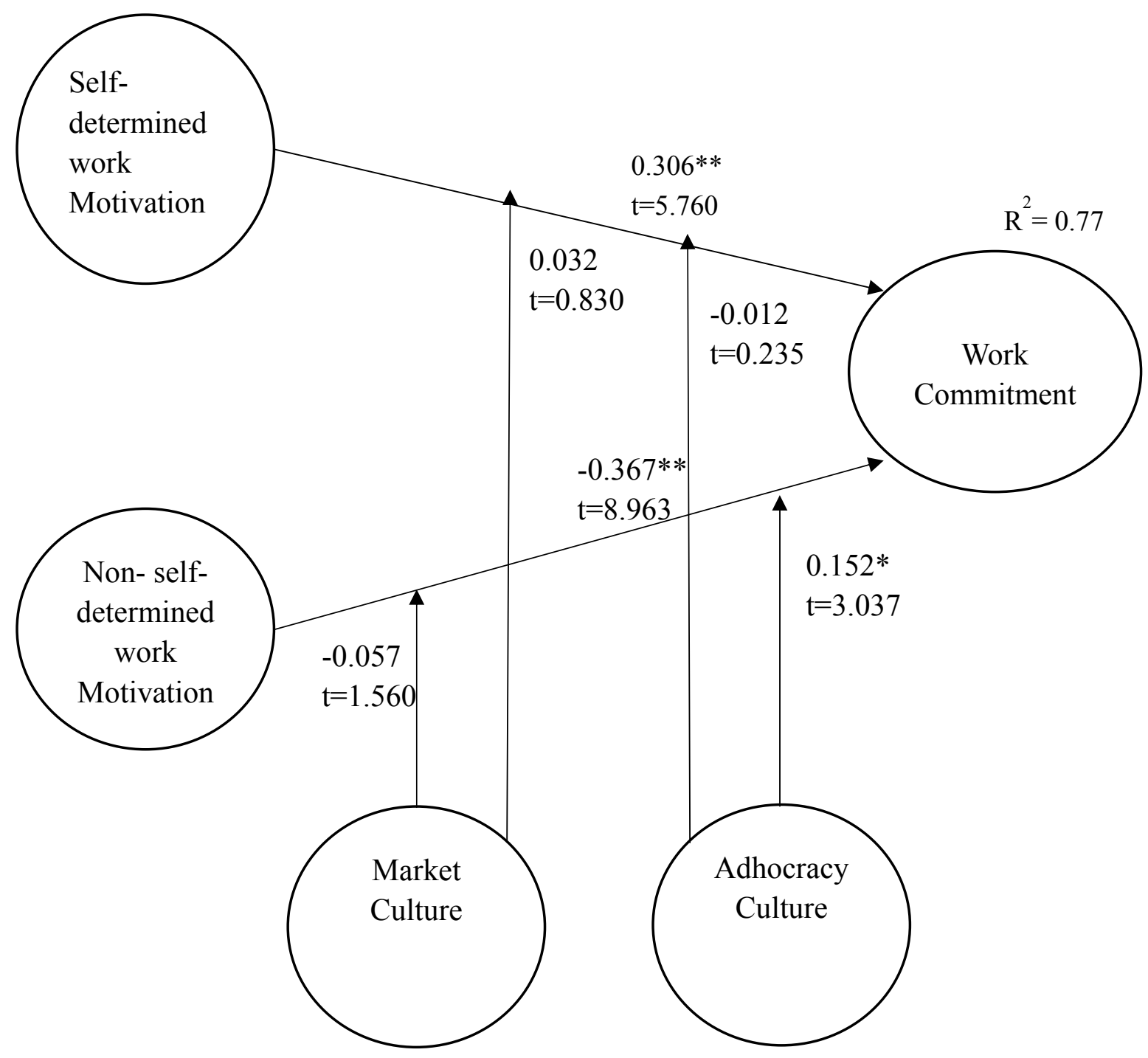

Figure 2. Structural Model with Moderator

Earlier, hypothesis 1 anticipated that adhocracy culture will moderate the relationship between self-determined work motivation and work commitment which was not accepted $(\beta=$ $-0.012, \mathrm{t}=0.235, \mathrm{p}>0.1)$. Hypothesis 2 was supported and adhocracy culture was seen to significantly moderate $(\beta=0.152, \mathrm{t}=3.037, \quad \mathrm{p}<0.01)$ the relationship between non-self-determined work motivation and work commitment. Thereafter, the relationship between self-determined work motivation and non-self-determined work motivation was not found to be moderated significantly by market culture $(\beta=-0.032, t=0.830, p>0.1),(\beta=-0.057$, $\mathrm{t}=1.560, \mathrm{p}>0.05)$ as stated under $\mathrm{H} 3, \mathrm{H} 4$ respectively. The $\mathrm{R}^{2}$ value of 0.773 was greater than 
the 0.35 (significant) value as proposed by Cohen (1988). Figure 2 and Table 2 summarizes the findings of the structural model analysis (hypotheses testing).

Table 2. Hypotheses Result

\begin{tabular}{|c|c|c|c|c|c|c|c|c|c|c|}
\hline Hypotheses & Relationship & Std. Beta & Std. Error & T-Value & P- Value & Result & VIF & $\mathrm{R}^{2}$ & $\mathrm{f}^{2}$ & $\mathrm{Q}^{2}$ \\
\hline $\mathrm{H} 1$ & $\mathrm{SDM}^{*} \mathrm{ADHO} \rightarrow \mathrm{WC}$ & -0.012 & 0.053 & 0.235 & 0.407 & Not supported & 3.434 & 0.77 & 0.001 & 0.439 \\
\hline $\mathrm{H} 2$ & $\mathrm{NSDM}^{*} \mathrm{ADHO} \rightarrow \mathrm{WC}$ & 0.152 & 0.05 & 3.037 & 0.001 & Supported & 3.398 & & 0.034 & \\
\hline $\mathrm{H} 3$ & $\mathrm{SDM}^{*} \mathrm{MAR} \rightarrow \mathrm{WC}$ & 0.032 & 0.039 & 0.83 & 0.203 & Not supported & 1.787 & & 0.003 & \\
\hline $\mathrm{H} 4$ & $\mathrm{NSDM}^{*} \mathrm{MAR} \rightarrow \mathrm{WC}$ & -0.057 & 0.036 & 1.56 & 0.06 & Not supported & 1.573 & & 0.009 & \\
\hline
\end{tabular}

$* * * \mathrm{p}<0.01 ; * \mathrm{p}<0.05$

[NSDM: Non-self-determined motivation; SDM: self-determined motivation; WC: Work commitment; ADHO: Adhocracy; Mar: Market].

Overall strength of the model was ascertained by calculating the effect size for the endogenous variables. By noticing $\mathrm{f}^{2}$ values in Table 2 , it is apparent that there was one relationship with medium effect size.

Additionally, following the trends of PLS, predictive relevance of the model was also determined. If $\mathrm{Q}^{2}$ value is greater than 0 it indicates the predictive relevance of the model for a certain endogenous construct (Hair et al. 2014). It can be seen from Table 2 that $\mathrm{Q}^{2}$ value for the endogenous construct is more than 0 indicating sufficient predictive relevance for the model.

\section{Discussion}

Hypothesis 1 is not supported which shows inability of adhocracy culture to moderate the relationship between self-determined work motivation and work commitment. It is consistent with the study of Moynihan and Pandey (2007) who did not come up with significant findings, when they investigated organizational predictors of public service motivation. Panagiotis, Alexandros and George (2014) have established a negative relationship between adhocracy culture and motivational factors of collegiality and working properties. Findings of the present study are contradictory with previous researches in which social environment and individual differences such as autonomous causality orientation was found to impact work motivation, performance and commitment (Gagne \& Deci, 2005). Moreover, past studies have demonstrated the moderating effect of organizational characteristics connected with organizational culture, such as level of interpersonal social communication and level of mentoring socialization in the relationship between intrinsic motivation and job engagement (Park \& Word, 2009). Results of Joo and Shim's (2010) study revealed that organizational learning culture moderates the association between psychological empowerment (proficiency and self-determination) and organizational commitment. 
Hypothesis 2 is supported and showing that adhocracy organizational culture moderates the relationship between non-self-determined work motivation and work commitment. Before adding adhocracy culture, the relationship between NSDM and work commitment was negative and when adhocracy was added as a moderator, the relationship turned into positive. Adhocracy culture has played its role well as a moderator. These findings are also in line with previous researches. Researchers found that organizational culture was a significant element to influence employees' motivation level (May, Bandar, Hutasuhut, \& Yahya, 2014; Panagiotis et al., 2014). Furthermore, Franco, Bennett, and Kanfer (2002) indicated that components of adhocracy such as dynamicity and innovations also encourage public service motivation.

Organizational culture has been proved to moderate and mediate the association between numerous theoretic concepts such as justice perceptions and leader-member exchange (Erdogan, Liden, \& Kraimer, 2006). Researchers have proposed that public service motivation is least related to employees and more associated with PSM standards that are shared by organization and personnel's and the possibilities to perform in coherence with the standers tendered by the organization. Therefore, organizational culture can improve or diminish PSM (Christensen \& Wright, 2011).

According to Spector (2003) factors that motivate or demotivate employees, significantly influence their feelings and attitudes toward their work. Besides their motivation and job satisfaction is influenced by the way they perceive organizational culture. Additionally, it is documented that the association between organizational culture and job satisfaction is supported by the interaction of specific motives, needs and organizational culture (Hon \& Leung, 2011).

Hypotheses 3 and 4 are not supported which reflects that market type of organizational culture does not moderate the relationship between SDM, NSDM and work commitment. It may be because of the possibility that market culture and academics possess different values (Schimank, 2005). It is also consistent with the study of Kurzdorfer (2016), who investigated the impact of organizational culture on public service motivation and indicated that only market culture was not emerged as a dominant culture in universities. Regardless of the increased competitive orientation of universities, the emphasis on production and market share does not appear to be yet applicable to universities and institutes, which are mainly financed by the government and predetermined tuition dues. Besides, universities as government organizations are regularly susceptible to policy restructurings (Rainey, 2014) and therefore require to be enterprising and capable of becoming accustomed to innovations. The motivation on accomplishing innovations equals the research element of universities (Kurzdorfer, 2016).

\section{Conclusion}

For survival and advancement, both public and private, universities require committed staff. The findings support the significance of organizational culture as an indispensable aspect to augment work motivation and thereby boosting academics' work commitment. Specifically, the findings of this study suggest that a focus on adhocracy (innovation) culture can change 
the direction of relationship between non-self-determined work motivation and work commitment from negative to positive. Academics who are even not working for idealism and altruistic reasons can be committed to their work, if universities provide an innovative and autonomy culture, and opportunities for personal development. Therefore, policies should be made for the establishment of innovative and dynamic organizational culture that focus on audacity, novelty, individual initiative and autonomy.

The findings of the study revealed organizational culture as a significant predictor of work commitment. It may be because of the possibility that the higher education commission in Pakistan has focused more on research. Promotion, salary and incentives of university academics are based on the quantity of published research papers (Hoodbhoy, 2017). Therefore, academics emphasized more on research than teaching. Overall, Asian culture is considered collectivistic but now due to globalization and competitive environment it has embraced characteristics of individualistic culture. Academics are more concerned with extrinsic rewards. This situation can be improved by highlighting the importance of teaching and by acknowledging only quality research, and by giving equivalent importance to teaching as well as research as per criteria for pay and promotions. Besides, the level of work motivation and work commitment can be enhanced by delivering training and development plans for the deans and head of the departments in universities, for embracing new roles as facilitators.

The results of the study cannot have a high degree of generalizability due to contextual nature. Upcoming studies may be conducted on a larger sample, distributed across multiple geographic areas in both public and private sectors to augment the generalizability of the research. Besides, interviews may be conducted to take the real picture of organizational culture. The influence of individual and situational factors on work commitment were investigated in the current study. Future research should study other contextual variables as moderators or mediators in different cultural context. Particularly, further research is suggested to explore the effects of personal factors on work motivation and work commitment, and investigate the preferred organizational culture along with the existing culture.

\section{References}

Alvi, H. A., Hanif, M., Adil, M. S., Ahmed, R. R., \& Vveinhardt, J. (2014). Impact of organizational culture on organizational commitment and job satisfaction.

European Journal of Business and Management, 6(27), 30-39.

Becker, T. E. (1992). Foci and bases of commitment: Are they distinctions worth making? Academy of Management Journal, 35(1), 232-244. https://doi.org/10.2307/256481

Becker, T. E. (2009). Interpersonal commitment. In H. J. Klein, T. E. Becker, \& J. P. Meyer (Eds.), Commitment in organizations: Accumulated wisdom and new directions (pp. 137-178). Florence, KY: Routledge/Taylor and Francis Group. 


\section{Macrothink Institute ${ }^{\text {TM }}$}

Bland, C. J., Center, B. A., Finstad, D. A., Risbey, K. R., \& Staples, J. (2006). The impact of appointment type on the productivity and commitment of full-time faculty in research and doctoral institutions. The Journal of Higher Education, 77(1), 89-123.

https://doi.org/10.1080/00221546.2006.11778920

Blau, G., Paul, A., \& St. John, N. (1993). On developing a general index of work commitment. Journal of Vocational Behavior, (42), 298-314. https://doi.org/10.1006/jvbe.1993.1021

Brown, J., \& Sheppard, B. (1997, August 25-30). Teacher librarians in learning organizations. Paper Presented at the Annual Conference of the International Association of School Librarianship. Retrieved from https://files.eric.ed.gov/fulltext/ED412959.pdf

Cameron, K. S., \& Quinn, R. E. (1999). Diagnosing and changing organizational culture-based on the competing values framework. Reading, MA: Addison-Wesley.

Christensen, R. K., \& Wright, B. E. (2011). The effects of public service motivation on job choice decisions: Disentangling the contributions of person-organization fit and person-job fit. Journal of Public Administration Research and Theory, 21(4), 723-743. https://doi.org/10.1093/jopart/muq085

Cohen, A. (2003). Multiple commitments in the workplace: An integrative approach. Mahwah, NJ: Lawrence Erlbaum Associates.

Cohen, J. (1988). Statistical power anallysis for the behavioral sciences (2nd ed.). Hillsdale, NJ: Lawrence Erlbaum .

Colyer, S. (2000). Organizational culture in selected Western Australian sport organizations. Journal of Sport Management, 14, 321-341.

Cucu-Ciuhan, G., \& Guită-Alexandru, I. (2014). Organizational culture versus work motivation for the academic staff in a public university. Procedia - Social and Behavioral Sciences, 127, 448-453. https://doi.org/10.1016/j.sbspro.2014.03.288

Day, C. (2000). Stories of change and professional development: The costs of commitment. In C. Day, A. Fernandez, T. Hauge \& J. Moller (Eds.), The life and work of teachers: International perspectives in changing times (pp. 109-129). London: Falmer Press.

De Jesus, S. N., \& Lens, W. (2005). An integrated model for the study of teacher motivation. Applied Psychology, 54(1), 119-134. https://doi.org/10.1111/j.1464-0597.2005.00199

Deal, T., \& Kennedy, A. (1982). Corporate cultures: The rites and rituals of corporate life. Reading.MA: Addison-Wesley.

Deci, E. L. (1971). Effects of externally mediated rewards on intrinsic motivation. Journal of Personality and Social Psychology, 18(1), 105-115. https://doi.org/10.1037/h0030644

Deci, E. L., \& Ryan, R. M. (1985). Intrinsic motivation and self-determination in human behavior. New York: Plenum. 
Deci, E. L., \& Ryan, R. M. (2000). The "What" and "Why" of goal pursuits: Human needs and the self-determination of behavior. Psychological Inquiry, 11(4), 227-268. https://doi.org/10.1207/S15327965PLI1104_01

Divkan, B., Sartipi, V., Zanganeh, I., \& Rostami, R. (2013). Relationship between organizational justice with job satisfaction and organizational commitment in physical education organizations of Tehran Islamic Azad university East Tehran branch. Advances in Environmental Biology, 7(6), 1162-1167. Retrieved from http://www.aensiweb.com/old/aeb/2013/1162-1167.pdf

Erdogan, B., Liden, R. C., \& Kraimer, M. L. (2006). Justice and leader-member exchange: The moderating role of organizational culture. Academy of Management Journal, 49(2), 395-406. https://doi.org/10.5465/AMJ.2006.20786086

Fornell, C., \& Larcker, D. F. (1981). Evaluating structural equation models with unobservable variables and measurement error. Journal of Marketing Research, 18(1), 39-50. https://doi.org/10.2307/3151312

Franco, L. M., Bennett, S., \& Kanfer, R. (2002). Health sector reform and public sector health worker motivation: A conceptual framework. Social Sciences \& Medicine, 54, 1255-1266. https://doi.org/10.1016/S0277-9536(01)00094-6

Fransson, G., \& Frelin, A. (2016). Highly committed teachers: What makes them tick? A study of sustained commitment. Teachers and Teaching: Theory and Practice, 22(8), 896-912. https://doi.org/10.1080/13540602.2016.1201469

Gagne', M., \& Deci, E. L. (2005). Self-determination theory and work motivation. Journal of Organizational Behavior, 26, 331-362. https://doi.org/10.1002/job.322

Gagné, M., Forest, J., Vansteenkiste, M., Crevier-Braud, L., van den Broeck, A., Aspeli, A. K., ... Westbye, C. (2015). The Multidimensional Work Motivation Scale: Validation evidence in seven languages and nine countries. European Journal of Work and Organizational Psychology. https://doi.org/10.1080/1359432X.2013.877892

Gagne, M., \& Koestner, R. (2002). Self-determination theory as a framework for understanding organizational commitment. Paper presented at the annual meeting of the Society for Industrial and Organizational Psychology. Toronto, Canada.

Gholami, R., Sulaiman, A. B., Ramayah, T., \& Molla, A. (2013). Senior managers' perception on green information systems (IS) adoption and environmental performance: Information Management, 50(7), 431-438. https://doi.org/ 10.1016/j.im.2013.01.004

Gupta, N., \& Gupta, R. (2014). Impact of work motivation on organizational commitment. International Journal of Education and Management, 4(1), 56-60.

Hair, J. F., Hult, G. T. M., Ringle, C. M., \& Sarstedt, M. (2014). A primer on partial least squares structural equation modeling (PLS-SEM). Thousand Oaks, CA: Sage.

Aziz, H. H. A., \& Rizkallah, A. (2015). Effect of organizational factors on employees' 
generation of innovative ideas: Empirical study on the Egyptian software development industry. Euro Med Journal of Business, 10(2), 134-146. https://doi.org/10.1108/EMJB-12-2014-0044

Heinz, M. (2015). Why choose teaching? An international review of empirical studies exploring student teachers' career motivations and levels of commitment to teaching. Educational Research and Evaluation, 21(3), 258-297. https://doi.org/10.1080/13803611.2015.1018278

Hon, A. H. Y., \& Leung, A. S. M. (2011). Employee creativity and motivation in the Chinese context: The moderating role of organizational culture. Cornell Hospitality Quarterly, 52(2), 125-134. https://doi.org/10.1177/1938965511403921

Hoodbhoy, P. (2017, July 1). Pakistan's professor mafia. Dawn. Retrieved from https://www.dawn.com/news/1342483

Imran, R., Allil, K., \& Mahmoud, A. B. (2017). Teacher's turnover intentions: Examining the impact of motivation and organizational commitment. International Journal of Educational Management. 31(6), 828-842. https://doi.org/10.1108/IJEM-05-2016-0131

Joo, B. B., \& Shim, J. H. (2010). Psychological empowerment and organizational commitment: The moderating effect of organizational learning culture. Human Resource Development International Publication, 13(4), 425-441. https://doi.org/10.1080/13678868.2010.501963

Karakuş, M., \& Aslan, B. (2009). Teachers' commitment focuses: A three-dimensioned view. $\begin{array}{llll}\text { Journal of Management } & \text { Development, 28(5), 425-438. }\end{array}$ https://doi.org/10.1108/02621710910955967

Khan, A. (2016, April 24). Brain drain alarming as $2.765 \mathrm{~m}$ went abroad in five years. The Nation. Retrieved from http://nation.com.pk/national/24-Apr-2016/brain-drain-alarming-as2-765m-went-abroad-in-five-years

Klassen, R. M., Al-Dhafri, S., Hannok, W., \& Betts, S. M. (2011). Investigating pre-service teacher motivation across cultures using the Teachers' Ten Statements Test. Teaching and Teacher Education, 27, 579-588. https://doi.org/10.1016/j.tate.2010.10.012

Krog, A. (2014). The relationship between organizational culture and work engagement: A multilevel investigation (Master thesis). Retrieved from https://www.duo.uio.no/bitstream/handle/10852/39783/The-relationship-between-organizatio nal-culture-and-work-engagement--A-multilevel-investigation.pdf? sequence $=1$

Kurzdorfer, N. (2016). The impact of organizational culture on public service motivation (Bachelor Thesis). Retrieved from http://essay.utwente.nl/70364/

Lazear, E. P. (1998). Personnel economics for managers. New York: John Wiley \& Sons.

Lee, C.-C., \& Chen, C.-J. (2013). The relationship between employee commitment and job attitude and its effect on service quality in the tourism industry. American Journal of 
Industrial and Business Management, 3(2), 196-208. Retrieved from http://www.scirp.org/journal/PaperInformation.aspx?PaperID=30131

Lin, C. (2017). Exploring career commitment and turnover intention of high-tech personnel: A socio-cognitive perspective. The International Journal of Human Resource Management. https://doi.org/10.1080/09585192.2017.1380061

Lok, P., \& Crawford, J. (2001). Antecedents of organizational commitment and the mediating role of job satisfaction. Journal of Managerial Psychology, 16(8), 594-613. https://doi.org/10.1108/EUM0000000006302

Martins, N., \& Martins, E. (2003). Organizational culture. In S. P. Robbins, A. Odendaal, \& G. Roodt, (Eds.), Organizational Behavior: Global and Southern African Perspectives (pp. 379-400). Cape Town, South Africa: Pearson Education.

May, N. S., Bandar, N. F. A., Hutasuhut, I. J., \& Yahya, F. (2014, November 29-30). The relationship between organizational culture and work motivation among employees in hotel industry in Kuching, Sarawak. Paper presented at UUM International Conference on Governance. Retrieved from http://repo.uum.edu.my/id/eprint/13112

Morrow, P. C. (1993). The theory and measurement of work commitment. Greenwich, CT: JAI Press.

Mowday, R. T., Steers, R. M., \& Porter, L. W. (1979). The measurement of organizational commitment. Journal of Vocational Behavior, 14(2), 224-247. https://doi.org/10.1016/0001-8791(79)90072-1

Moynihan, D. P., \& Pandey, S. K. (2007). The role of organizations in fostering public service motivation. Public Administration Review, 67(1), 40-53. https://doi.org/10.1111/j.1540-6210.2006.00695.x

Ngeis-Isik, A., \& Gursel, M. (2013). Organizational culture in a successful Primary School: An ethnographic case study. Educational Sciences: Theory \& Practice, 13(1), 221-228.

Othman, C., \& Kasuma, J. (2017). Relationship of school climate dimensions and teachers' commitment. International Journal of Advanced and Applied Sciences, 4(3), 94-100.

Otis, N., \& Pelletier, L. G. (2005). A motivational model of daily hassles, physical symptoms, and future work intentions among police officers. Journal of Applied Social Psychology, 35(10), 2193-2214. https://doi.org/10.1111/j.15591816.2005.tb02215.x

Panagiotis, M., Alexandros, S., \& George, P. (2014). Organizational culture and motivation in the Public Sector. The Case of the City of Zografou. Procedia Economics and Finance, 14, 415-424. https://doi.org/ 10.1016/S2212-5671(14)00730-8

Park, S. M., \& Word, J. (2009). Motivated to serve: An empirical examination of motivation and consequences in the public and nonprofit organizations. International Public Service Motivation Research Conference, 66(4), 505-514.

Pinder, C. C. (1998). Work motivation in organizational behavior. Upper Saddle River, NJ: 
Prentice Hall.

Quinn, R. E., \& Rohrbaugh, J. (1983). A spatial model of effectiveness criteria: Towards a competing values approach to organizational analysis. Management Science, 29(3), 363-377. https://doi.org/10.1287/mnsc.29.3.363

Rainey, H. G. (2014). Understanding and managing public organizations. San Francisco, CA: Jossey Bass.

Redman, T., \& Snape, E. (2005). Unpacking commitment: Multiple loyalties and employee behavior. Journal of Management Studies, 42(2), 301-328. https://doi.org/10.1111/j.1467-6486.2005.00498.x

Reichers, A. E. (1985). A review and reconceptualization of organizational commitment. The Academy of Management Review, 10(3), 465-476. Retrieved from http://www.jstor.org/stable/258128

Richard, O. C., McMillan-Capehart, A., Bhuian, S. N., \& Taylor, E. C. (2009). Antecedents and consequences of psychological contracts: Does organizational culture really matter? Journal of Business Research, 62(8), 818-825. https://doi.org/10.1016/j.jbusres.2008.04.001

Richer, S. F., Blanchard, C., \& Vallerand, R. J. (2002). A motivational model of work turnover. Journal of Applied Social Psychology, 32(10), 2089-2113. https://doi.org/10.1111/j.1559-1816.2002.tb02065.x

Ringle, C. M., Wende, S., \& Becker, J.-M. (2015). Smart PLS 3. Boenningstedt: Smart PLS $\mathrm{GmbH}$.

Schimank, U. (2005). New public management and the academic profession: Reflections on the German situation. Minerva, 43(4), 361-376. https://doi.org/10.1007/s11024-005-2472-9

Schneider, B., Ehrhart, M. G., \& Macey, W. H. (2013). Organizational climate and culture. The Annual Review of Psychology, 64, 361-388. Retrieved from 10.1146/annurev-psych-113011-143809

Sempane, M. E., Rieger, H. S., \& Roodt, G. (2002). Job satisfaction in relation to organizational culture. SA Journal of Industrial Psychology, 28(2), 23-30.

Shore, L. M., Newton, L. A., \& Thornton, G. C. (1990). Job and organizational attitudes in relation to employee behavioral intentions. Journal of Organizational Behavior, 11(1), 57-67. https://doi.org/10.1002/job.4030110108

Siehl, C., \& Martin, J. (1990). Organizational culture: A key to financial performance? In B. Schneider (Ed.), Organizational Climate and Culture, (pp. 241-281). San Francisco, CA: Jossey-Bass.

Sinani, J. (2016). Motivational factors and organizational commitment of the educational institution's employee. Journal of Educational and Social Research, 6(1), 89-93. https://doi.org/10.5901/jesr.2016.v6n1p89 
Sinclair, C., Dowson, M., \& McInerney, D. M. (2006). Motivations to teach: Psychometric perspectives across the first semester of teacher education. Teachers College Record, 108(6), 1132-1154.

Sohail, B. A., Safdar, R., Saleem, S., Ansar, S., \& Azeem, M. (2014). Effect of work motivation and organizational commitment on job satisfaction: A case of education industry in Pakistan. Global Journal of Management and Business Research, 14(6), 41-46. Retrieved from journalofbusiness.org/index.php/GJMBR/article/view/1320

Sokro, E. (2012). Analysis of the relationship that exists between organizational culture, motivation and performance. Problems of Management in the 21st Century, 3, 106-119. Retrieved from www.scientiasocialis.lt/pmc/files/pdf/Sokro_Vol.3.pdf

Spector, P. E. (2003). Industrial and organizational psychology: Research and practice (3rd ed.). New York: John Wiley \& Sons.

Tella, A., Ayeni, C. O., \& Popoola, S. O. (2007). Work motivation, job satisfaction, and organizational commitment of library personnel in academic and research libraries in Oyo State, Nigeria. Library Philosophy and Practice, 9, 1-16. Retrieved from https://digitalcommons.unl.edu/libphilprac/118/

Tentama, F., \& Pranungsari, D. (2016). The roles of teachers' work motivation and teachers' job satisfaction in the organizational commitment in extraordinary schools. International Journal of Evaluation and Research in Education, 5(1), 39-45. Retrieved from files.eric.ed.gov/fulltext/EJ1094678.pdf

Towers, D. (2006). An investigation whether organizational culture is directly linked to motivation and performance through looking at Google Inc. An unpublished extended essay, $1-31$.

Tremblay, M. A., Blanchard, C. M., Taylor, S., Pelletier, L. G., \& Villeneuve, M. (2009). Work Extrinsic and Intrinsic Motivation Scale: Its value for organizational psychology research. Canadian Journal of Behavioural Science, 41(4), 213-226. https://doi.org/10.1037/a0015167

Ushie, B., Ogaboh, A. M., \& Okorie, C. (2015). Work environment and employees' commitment in Agro-based industries in Cross River State, Nigeria. Global Journal of Human Social Sciences, 15(6), 8-15.

Vandenberghe, C. (2009). Organizational commitments. In H. J. Klein, T. E. Becker, \& J. P. Meyer (Eds.), Commitment in organizations: Accumulated wisdom and new directions (pp. 99-135). Routledge/Taylor \& Francis Group.

Viseu, J., De Jesus, S. N., Rus, C., Canavarro, J. M., \& Pereira, J. (2016). Relationship between teacher motivation and organizational variables: A literature review. Paideia, 26(63), 111-120. https://doi.org/10.1590/1982-43272663201613

Vujcic, M. T., Oerlemans, W. G. M., \& Bakker, A. B. (2016). How challenging was your work today? The role of autonomous work motivation. European Journal of Work and 


\section{Macrothink}

International Journal of Learning and Development

ISSN 2164-4063 2018, Vol. 8, No. 1

Organizational Psychology, 26(1), 81-93. https://doi.org/10.1080/1359432X.2016.1208653

Wallach, E. J. (1983). Individuals and organizations: The culture match. Training and Development Journal, 37(2), 28-36.

Zardari, S. (2014). The sorry state of research at our universities and how to fix it. Dawn. Retrieved from www.dawn.com/news/1141829

\section{Copyright Disclaimer}

Copyright for this article is retained by the author(s), with first publication rights granted to the journal.

This is an open-access article distributed under the terms and conditions of the Creative Commons Attribution license (http://creativecommons.org/licenses/by/4.0/). 